\title{
Handout development on contextual based-approach to improve the problem solving ability of grade VII student
}

\author{
Alimatu Saqdiah ${ }^{1}$, Armiati $^{2}$, Yerizon $^{3}$ \\ ${ }^{123}$ Universitas Negeri Padang, Padang - Indonesia , (saqdiaha@yahoo.co.id)
}

\begin{abstract}
Problem solving ability is a very important to attainment of objectives mathematics learning. In fact, the problem solving ability of student is still low. One of the efforts to improve the problem solving ability is handout development on contextual based-approach. The purpose of this development research is to know the characteristics handout on contextual based-approach which are valid, practical, and effective. This development research uses a Plomp model consisting of three phases namely : preliminary, prototyping, and assessment. The instruments were used in this study are validation sheets for RPP and handout, questionnaire for teacher and students, sheets of observation, and test. Handout on contextual based-approach has been valid with validity was 3.58 and it was practical with practicality level of the according to the teachers' response gave $87,86 \%$ and students' response was $82.73 \%$. They also efective to improve the problem solving ability of student.
\end{abstract}

Keywords: contextual approach, problem solving ability.

\section{Introduction}

Mathematics is one field of study that has a role in various disciplines and supports the development of Science and technology. This is supported by the government policy number 58 in 2014 which states that mathematics is an important science in life even in the development of science. The purpose of learning mathematics is to improve the mathematical ability of students that consists of the ability to understand concepts, reasoning ability, communication skills, and problem-solving skills. Mathematical problem solving is one of the five process standards in the National Council of Teachers of Mathematics, in addition to communication, reasoning and evidence, connections, and mathematical representations. The ability to solve problems is an important thing that the students must have in achieving the curriculum (Husna, 2013).

In terms of achieving the objectives of mathematics learning, an effective and a more creative way of conveying the concepts of mathematics and preparing the learning device is needed, that is, learning mathematics should be emphasized on the relationship between mathematical concepts with the experience of students every day, and learning instruments used by teachers can help students to understand abstract mathematics and can construct students' knowledge. 
Learning instruments play an important role in a learning process. Learning instruments are the instruments needed and used in managing teaching and learning process (Trianto, 2010). In addition, learning instruments are a number of materials, tools, media, instructions and guidelines to be used in the learning process (Nabila, 2017).

Learning instruments can be lesson plans (RPP) and teaching materials. This article only discusses teaching materials in the form of a handout which is part of the thesis written by Alimatu Saqdiah entitled "Learning instruments development on contextual based-approach to improve problem solving ability of grade VII students".

Teaching materials are structured to be a guide for educators and students in the learning process, and can be used as an evaluation tool to achieve learning outcomes. One of the teaching materials that can support other teaching materials is handout. The structures of handouts are based on the basic competencies that students must achieve by considering the characteristics, materials, and cognitive abilities of students (Gusmania, 2012).

Based on observations made in some junior high schools in Sungai Limau sub-district; SMP N 5 Sungai Limau on June $4^{\text {th }} 2015$, SMP N 4 Sungai Limau on June $5^{\text {th }} 2015$, SMP N 3 Sungai Limau on June $8^{\text {th }} 2015$, and SMP N 2 Sungai Limau on June $9^{\text {th }} 2015$, the teaching materials commonly used in the learning process is a compulsory book that is accompanied by LKPD from the publisher. Compulsory books available in schools has some shortcomings, such as: limited books owned by students, compulsory books use language and illustrations that are not communicative so that it is difficult for students to understand, and the absence of nuances which can inspire students' affective. The use of LKPD as a companion in learning mathematics less meets the needs of students and the presentation of the materials is only materials' summary and questions of exercises, which is certainly not enough as a reference learning. In learning, only some students are able and have willingness to look for other references for learning, but mostly they depend on the teacher. This condition certainly leads to a learning environment which is dominated by teacher. This indicates that the need for teaching materials in the form of handouts is needed as reference materials for students to enrich their knowledge.

Through interviews with mathematics teachers at SMP Negeri 3 Sungai Limau, teachers provide information that students think mathematics is a difficult lesson, almost a half students are not happy with mathematics subject, so students tend to view mathematics learning as a tedious process. That mathematics nature is difficult for students is because mathematics itself is a science that requires an ability and reasoning in learning (Affandi, 2017). Students' difficulties in doing mathematics problems provided by teacher so that they only copy from friends who are considered have the ability or wait for answers from teacher. This will not happen if the learning utilizes the existing environment. This is in line with the results of the research conducted by John Dewey that states that students can learn well if what is learned related to activities or events that occur in their environment (Hosnan, 2014).

This condition has an impact on the students' low ability of mathematics problem solving. This is consistent with the result of mathematics problem solving test for students of grade VII of SMP N 3 Sungai Limau on the subject matter of integer operation and fraction of academic year 2014/2015. From 198 students, only 75 students (about 38,17\%) who get the value of $\geq$ Minimum Achievement Criteria (KKM). This is in line with the research results of Dewi Kirana in SMP Negeri 5 Sungai Limau in which the test of mathematics problem solving ability was given to 61 students, only 32 students (about 52,46\%) who were able to finish well. This is because there were students who still do not understand the problems well, the error in the calculation and did not make solutions to the given problems. It can be concluded that students' ability in mathematics problem solving is not optimal yet.

One alternative that can be done in improving the mathematics problem solving skills of students is to develop mathematics handouts. The development of mathematics handouts should be tailored to 
the needs and characteristics of students. This is reinforced by Rick Hunter Simanungkalit who says that the development of learning devices that do not fit the needs and characteristics of students will have an impact on the learning stages of students (Simanungkalit, 2016). The reason for the importance of developing mathematics handouts is the availability of materials in accordance with the demands of the curriculum, target characteristics, and the demands of solving learning problems.

The right approach used in the development of mathematics handouts to achieve that goal is the contextual approach. Learning that can provide optimal results and can further facilitate students' learning is the contextual approach. The contextual approach is a learning strategy that emphasizes the full process of involving the students in order to be able to find the materials learned and can relate it to the real life, thus encourages them to apply it in their lives. Mathematics learning with a contextual approach is a mathematics learning that combines the content of the lessons with the experience and everyday circumstances of the students both as an individual and a part of society (Sari, 2014). One of the benefits of the contextual approach is a learning that can help teachers to connect the content of teaching materials with real-world situations (Hutagaol, 2013). By applying the contextual approach, students can achieve more meaningful learning outcomes. This is in line with Jhonson's explanation which states that the contextual approach is able to present a more meaningful learning process because it starts from the knowledge and practice of students and then attributed to the materials being studied (Gilar, 2016).

Based on the problems above then it is developed a mathematics handout based on a contextual approach to improve the problem solving skills of students of grade VII in junior high schools. Contextual-based approach handouts are instructional materials specially designed where the learning materials are sourced from some of the literatures which are relevant to the basic competencies and subject matters taught by referring to contextual approach learning.

The formulation of the problem in this research is "what are the characteristics of contextual-based handout development based on the mathematics learning of grade VII of junior high school students which are valid, practical and effective in improving students' mathematics problem solving skills?"

Based on the formulation of the problems that have been stated above, the purpose of this study is to know the characteristics of contextual-based handout development to mathematics learning of grade VII students of junior high schools which are valid, practical, and effective in students' mathematics problem solving skills.

\section{Method}

This type of research is a developmental study using the Plomp model, which consists of three phases, namely preliminary research phase, prototyping stage or assessment stage, and assessment phase (Plomp, 2013). The preliminary research phase consists of needs analysis, curriculum analysis, conceptual analysis and students analysis. In the prototyping stage, the prototype is done with a formative evaluation. Phase of development or prototype (prototyping stage) consists of prototype 1, that is self evaluation and expert review; prototype 2 is one to one; prototype 3 is small group; prototype 4 that is field test. In the assessment phase, field tests were conducted on Grade VII of SMPN 3 Sungai Limau to see the practicality and effectiveness. The data of the research were collected through self-evaluation sheets with average validity of 3.19 (valid criteria), validation sheets with average validity of 3.38 (very valid criteria), observation sheets with average validity of 3.26 (very valid criteria), and interview guidelines with average validity of 3.14 (valid criteria), teacher response questionnaires with average validity of 3.12 (valid criteria), students' response questionnaires with average validity of 3.26 (very valid criteria), field notes with average validity of 3.00 (valid criteria), and final tests of mathematics problem solving ability with average validity of 3.53 (very valid criteria). Validation of the instrument was done by three lecturers of Mathematics, one lecturer of Indonesian language, and one lecturer of Educational Technology. 


\section{Results and Discussion}

\section{Initial Investigation (Preliminary Research)}

The purpose of this stage is to define the requirements required in the development of mathematics learning instruments. There are four main steps in this phase:

\section{Needs Analysis}

At this stage, we collect information on the problems contained in mathematics learning, by observing the implementation of learning activities, interviewing mathematics teachers and students, in which it is concluded that teachers are more likely use conventional models in the learning process rather than using particular learning models and approaches. During the learning process, students use compulsory books and LKPD from the publishers, in which there is still a shortage of these teaching materials, then this is not enough to be used as a reference for students to optimize their mathematics problem solving skills. In addition to observations and interviews, questionnaires were also given to 30 students about the characteristics of teaching materials, with the conclusion that the materials that the students want are those that can support the existing teaching materials, with a pretty interesting display along with illustrations of images according to the materials and able to deliver the abstract materials become more concrete, and the paper size used is A4.

\section{Curriculum Analysis}

At this stage, a review of the curriculum of KTSP for the subject of mathematics grade VII for thesecond semester at SMP was done. This analysis serves as a guide in developing contextual-based approach mathematics handouts. Analysis for Material Competency Standards in the second semester is the development of indicators by using contextual approach learning to organize the materials and determine the learning objectives to be achieved in every meeting.

In the second semester there are three Competency Standards: 1) Competency Standard 4 uses Venn set and Venn diagrams in problem solving, 2) Competency Standard 5 is to understand the relationship of lines with lines, lines with angles, angles with angles, and to determine their sizes and 3) Competency Standard 6 is to understand the concept of quadrilaterals and triangles and determine their sizes. There are several indicators developed in Competency Standard 4, 5, and 6.

\section{Concept Analysis}

The concept analysis which was conducted on the subject of mathematics in grade VII of Junior high school at the Second Semester aims to determine the contents and subject matters needed in the development of learning tools, by identifying the main concepts taught, detailing and arranging them systematically.

The compositions of the material to be presented on the subject of the Set is the definition of the set, the membership of the set, representing a set, the empty set, the set of the universe, the subsets, the venn diagrams, the incisions and the combination of two sets, the difference of two sets, the complement, the use of venn diagrams for slices and aggregate set. Presentation of venn diagram materials were done after studying the materials of the subset, studying the subject matter in advance will facilitate students in declaring a set through a venn diagram. Furthermore, presentation of rectangular subject is the last material of the second semester in this research because studying the concept of angles, lines and triangles will facilitate students to find a concept on rectangles.

\section{Analysis of students}

The students of grade VII became the subject of this research in the experiment of contextual-based approach math- handout. The analysis was conducted on the students of grade VII of SMPN 3 Sungai Limau in the second semester of academic year 2016/2017. At this stage, there were five characteristics of the students: 1) Students were in formal operation stage where the average students were aged in the range of $11-14$ years; 2 ) students preferred to learn to discuss with other students; 3) students were not confident with the results of work, 4) Most students liked to group when doing an activity, for example when the teacher provides some excercises students prefer to do the them together with 
friends rather than doing individually; and 5) students were less focused and unmotivated in learning mathematics.

\section{Phase Prototyping Results (prototype design)}

1. Design of Learning instruments

Preliminary Research results serve as the basis for the development or manufacture of prototypes. Once the indicator is formulated, as well as the concept is established then the next step is to design a mathematical handout based on a contextual approach. The following will outline the mathematics handout based on the contextual approach that has been designed. Characteristics of contextualbased approach math handout are divided into several aspects, namely as follows.

\section{Aspects of Construction and Contents}

Materials and activities of students refer to contextual approach- based learning. The presentation of the material began with the presentation of the day-to-day problems of the students and related to the material to be studied. This presentation is a form of constructivism activity which is one component of a contextual approach. Constructivism is a theory whichnviews that students will learn more meaningful by working alone, discovering themselves, and constructing their own new knowledge or skills.

The material was presented with a sentence that was easily understood by students. The materials and indicators became the references in developing the problems in the handout. This is one example of the problems on the handout.

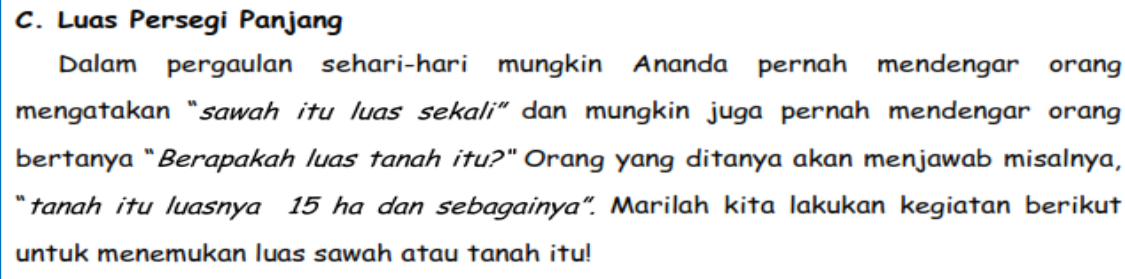

Students solved existing problems by discussing in the group. Working in a group can increase students' learning activities so that the community learns in the learning process.

In finding mathematics concepts, students were directed to construct their knowledge. This is the example of constructivism activities on handout.

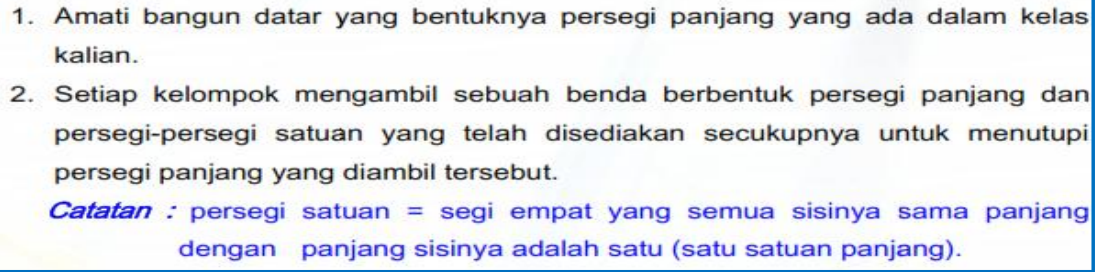

Furthermore, students were led to find mathematics concepts, such as finding the concept of rectangular area. This is the example of inquiry activities on the handout. 


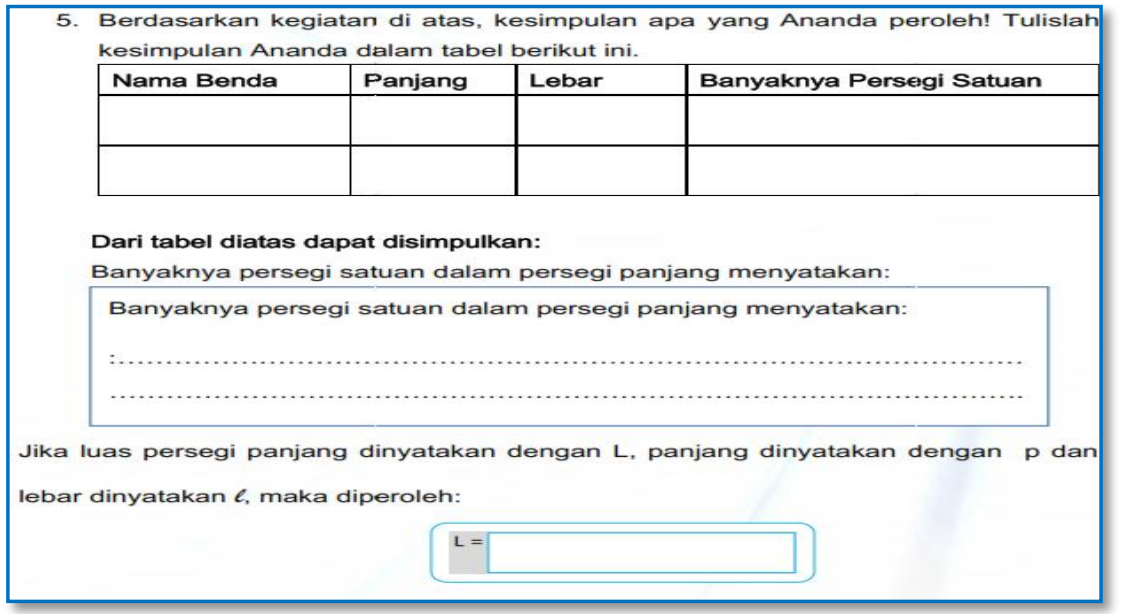

In solving the existing problems in the exercises in the handout, students were helped with questions that could train students' mathematics problem-solving abilities. This was because the questions were based on the mathematics problem solving indicator. This is one example of the problems with the exercise in the handout.

\section{Gatitan}

1. Ayah mempunyai sebidang kebun dengan panjang 20 meter dan lebar 10 meter. Ayah ingin memagari kebun tersebut agar aman dari gangguan luar. Berapakah panjang pagar yang harus dibuat Ayah agar bisa mengelilingi kebun dan bantulah Ayah menghitung banyaknya pohon pisang yang ada di kebun jika disekililing kebun ditanami pohon pisang dengan jarak tanam antar pohon 4 meter?

a. Tuliskanlah informasi yang Ananda peroleh dari masalah di atas (Diketahui dan ditanyakan)!

b. Dengan metode apa Ananda dapat menyelesaikan masalah tersebut?

c. Selesaikanlah permasalahan tersebut menggunakan metode yang telah Ananda tetapkan!

d. Apakah Ananda sudah yakin dengan hasil jawaban yang telah kamu diperoleh? Berikan alasanmu!

Furthermore, students were asked to present the results of the discussion in front of the class, to know the work of students and facilitate in equating the ideas of students. This activity is one component of the contextual approach of modeling.

After students did all the activities above, then above made a conclusion. They might draw conclusions in their own comprehension to make it easy to understand based on the learning activities the students have done. Here was the conclusion of the handout.

\section{KESIMPULAN}

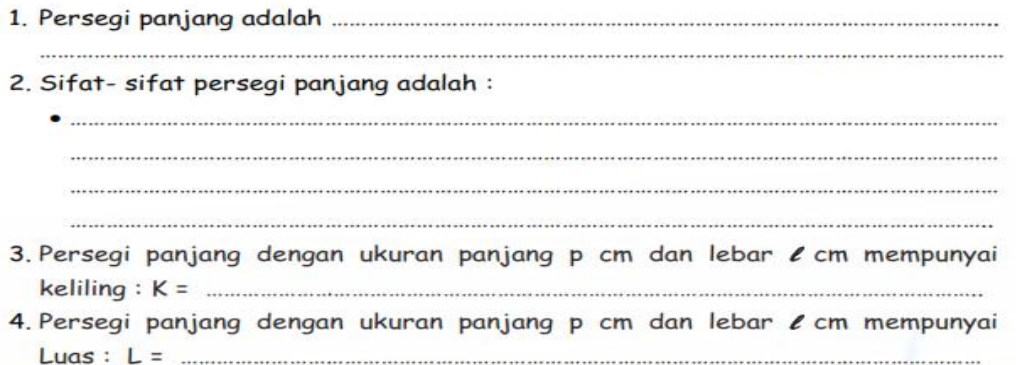

In addition to drawing conclusion, students were asked to do reflection activities to look back, reorganize, analyze again, clarify again, and reevaluate what has been learned. Here's a reflection on the handout. 


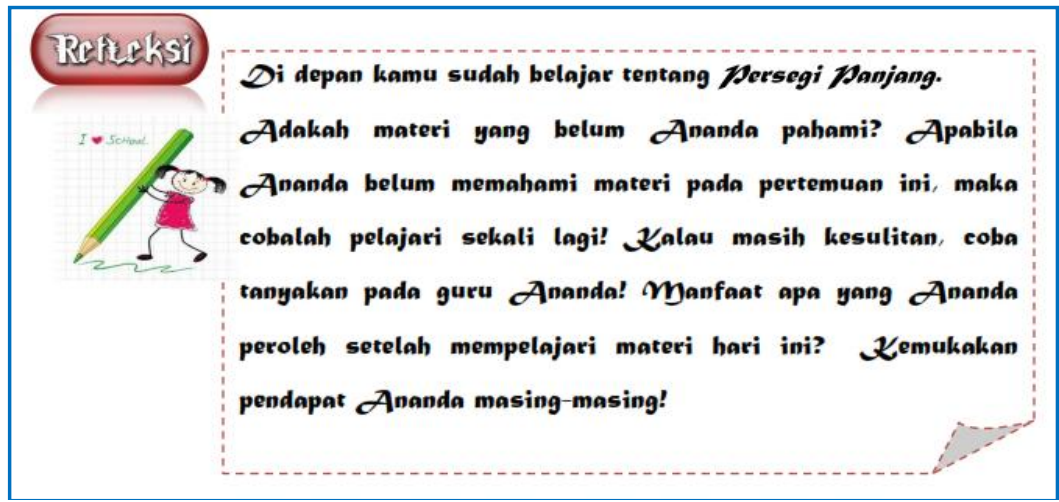

The final activity on this handout was conducting assessment activities. The obvious judgment on this handout was to provide an assessment for each student activity at the end of the meeting. Thus, one of the components of learning based on the contextual approach was fullfulled. The component meant was the authentic assessment.

1) Aspects of Language

Handout used the standard language in accordance with enhanced spelling (EYD). Handout uses simple and communicative language and in accordance with the level of intellectual ability of junior high school students grade VII so that the presentation of the material on the handout could be understood well by stuents. The questions in the handout were arranged with clear sentences so that they were able to direct students to get the expected answers.

3) Aspect of Presentation

Cover contained the identity of mathematics handouts based on contextual approaches, subjects, identity columns of students as the owner of handouts. Here is the cover design of a mathematics handout based on a contextual approach.

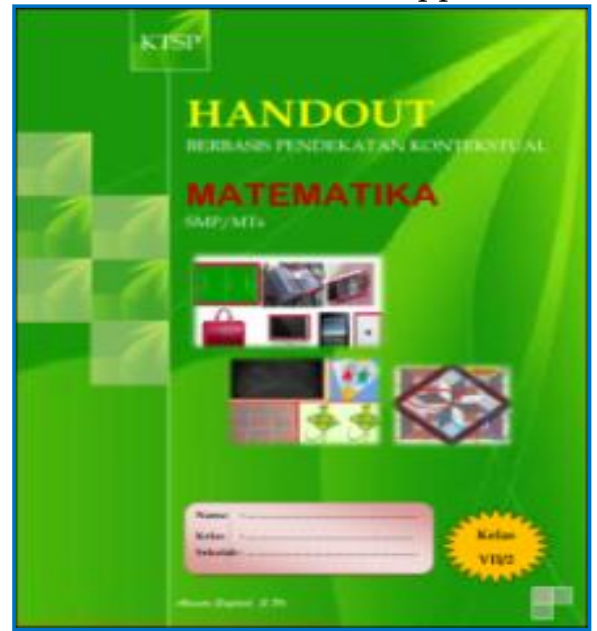

The cover page on the subtitle also came with a view of educational units, subjects, classes and semesters, subject matters and time allocation. This is one example of writing subtitle on handout.

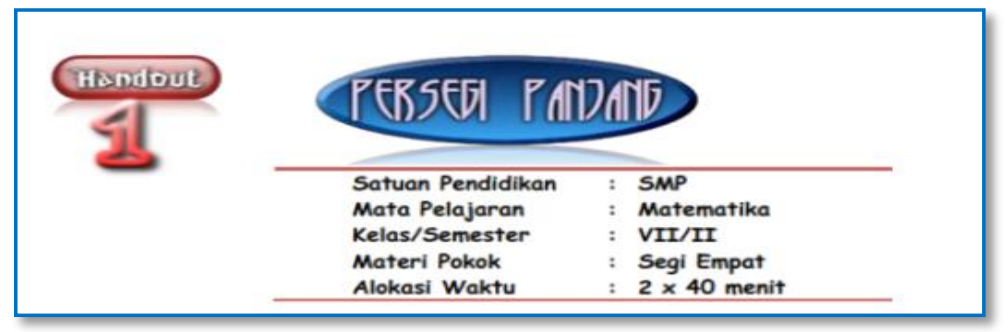


In the handout there are instructional instructions that served to guide students before implementing learning using the handout. The Example of instruction for using designed handout can be viewed in the following figure.

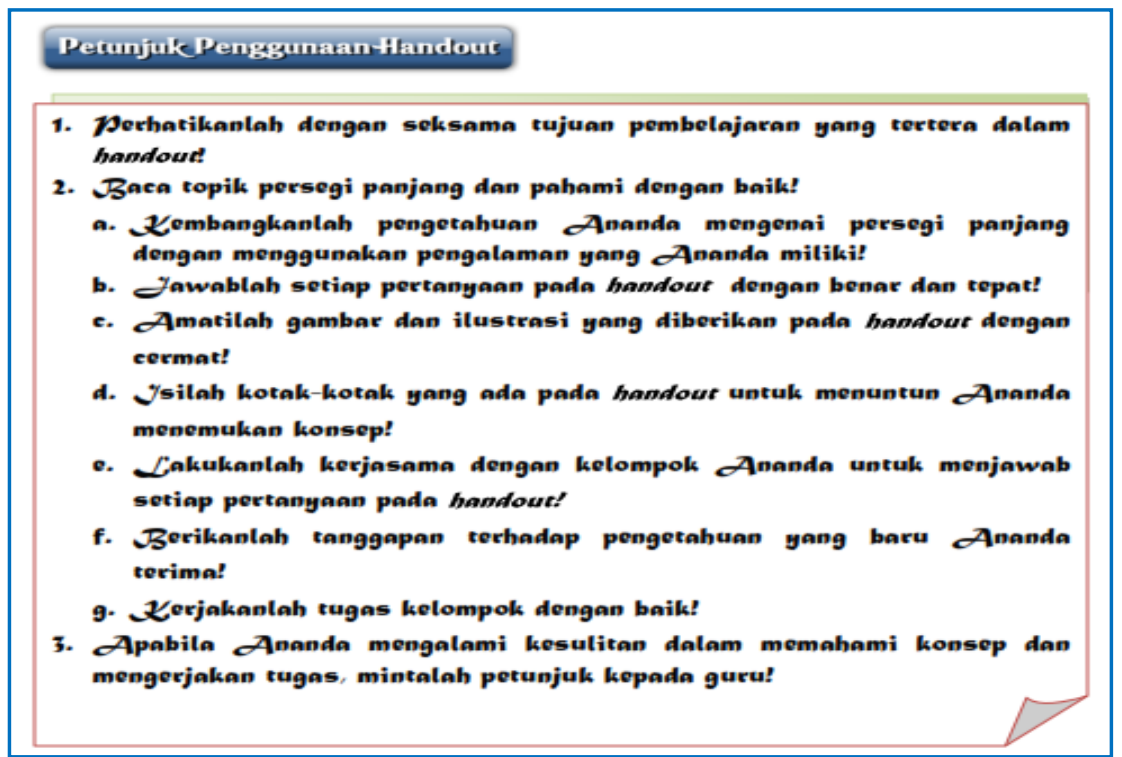

Handout also have words of wisdom for the readers in order to generate motivation for someone who reads it. Here is an example of the words of wisdom in the handout.

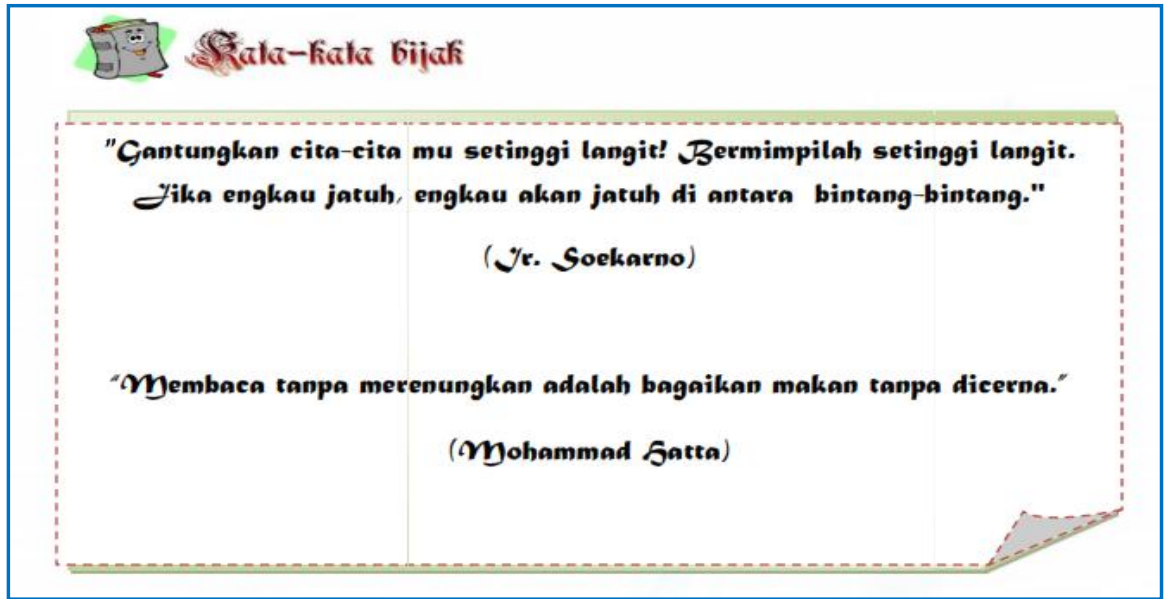

In addition, handout is also equipped with concept maps, so students can connect concepts during learning.

\section{Prototype 1}

Prototype 1 is an early stage of learning tools design. To obtain a valid device, there were two steps done in validating the handout which was self evaluation and expert review. Below is outlined the validation results of prototype handout that have been designed.

1) Self Evaluation Results

Self evaluation is correcting small mistakes against oneself. Before consulting and discussing to the experts, the first self-evaluation was conducted to the handout that has been designed. In general, many errors occur in typing words and punctuation which were not spaced 1, and the use of commas and commands (exclamation marks or question marks). The next error was visible on the precise size of the images' placement and the blank space to solve the questions was too little. 
2) Validation Results

Handout were first discussed with the supervisor, then validated to experts consisting of 5 validators. Lecturers who became validators come from 3 areas of expertise; mathematics, education technology and language.

Validation of handout were on several aspects of construction, content, linguistic aspects and aspects of graphics or appearance. During the validation process there were several revisions suggested by the validators. Based on the suggestion of the validators there were several things that needed to be fixed: the guidance section should use the proper numbering, adjust the issues in the handout with the context, replace the double- meaning images, provide fill boxes in the discussion columns, eliminate unnecessary activities, decrease background contrast of the background handout, and the need for concept maps and homework of students on handout. After the improvements, the validators provided an assessment of the handout that has been designed.

Handout validation results showed that for the construction aspect, the content, the language, and the aspect of graphics can be seen in Table 1. Table 1: Handout on contextual based-approach validation results

\begin{tabular}{lcc}
\hline Rated Aspecs & Validity Value & Category \\
The & 3.33 & valid \\
The Content & 3.24 & very valid \\
The Language & 3.75 & very valid \\
The Aspect of & 4,00 & very valid \\
\hline Overall & 3.58 & valid \\
\hline
\end{tabular}

Thus, it can be concluded that the contextual- based approach mathematics handout has

\section{Prototype 2}

been valid in terms of construction, content, language, and appearance.

Evaluation per person was done by asking students to comment on the handout that has been designed. In general, students were interested in the contextual- based approach mathematics handout, the language used was communicative, the workmanship was clear, the questions contained in handouts were easy to understand, and illustration drawings were easy to understand the materials. Based on the details of the implementation of this individual evaluation, in general, the revision was limited to the sentences only.

\section{Prototype 3}

The activities undertaken on prototype 3 were testing the handout practicality by means of small group evaluation. Small group evaluation was done by practicing handout that has been designed in a group of students consisting of 8 people. Evaluation of small groups was done for six times on the materials of rectangle, square, parallelogram, rhombus, kite-shape and trapezoid. At this stage the observation was done when the implementation of small group took place. The result of observation was there were some revisions of the handout, that was the improvement of the sentences of the questions, graphic making, the workmanship of the exercise, and the presentation activities. Based on these observations, a revision was made.

\section{Field Test Test Results}

In the assessment stage which was the prototype stage 4, field test was conducted in grade VII.2 at SMPN 3 Sungai Limau to see the practicality and effectiveness of contextual-based approach handout. Trial was done for 6 times on rectangular materials.

Based on the observation that has been done 6 times of meetings, the first meeting to the sixth meeting showed that in general, learning using contextual-based approach mathematics handout was practical to be implemented, the time spent for each learning step was effective, it was easy for the students to use and do the tasks on the handout, and teacher could guide students in learning. 
Constraints were faced only at the beginning of the trial. After several times, the learning process was carried out well in accordance with the planned time allocation.

The result of practicality test by using questionnaire of teachers' response gave $87,86 \%$ of practical value. Based on the criteria that have been made, then the handout on contextual based-approach was very practical. Seen from the questionnaire that was filled, teachers said that the handout-based contextual approach was easy to use, interesting, well understood, efficient, and useful for the students to learn math and understand the concept well and critical in investigating the problems.

The results of questionnaire of students' response showed that the level of practicality for the aspect of ease, the attractiveness aspect, the aspect of easy to be understood, handout benefits aspect , and for the time efficiency aspect, can be seen Table 2 .

Table 2: Student Response Questionnaire Results toward Handout On Contextual Based-Approach

Rated Aspecs Practicality Value (\%) Category

The Aspect of Ease

The Attractiveness Aspect

The Aspect of Easy to be Understood

Handout Benefits Aspec

The Time Efficiency Aspect

Overall Average
$83.33 \%$
$80.25 \%$
$85.00 \%$
$84.62 \%$
$75 \%$

$82.73 \%$ practical

practical

very practical

practical

practical

practical

Thus, it can be concluded that the contextual-based approach mathematics handout was practical.

Final test results were conducted to see the effectiveness of instructional instruments in terms of learning evaluations of students during the use of this lesson. The final test results of students were in the form of a description with 4 questions. This final test contained an indicator of understanding the problem, planning the settlement, solving the problem, and checking again. This test was performed to assess cognitive abilities with the ability to solve mathematics problems of students after learning by using mathematics handouts based on a contextual approach implemented on May 16th 2016. The number of the students who came in the daily tests were 29.

Based on the final test results, from 29 students who took the test, 23 students or $79.31 \%$ passed which meant that the value of students was above the determined KKM, and 6 students or $20.69 \%$ didnot pass which meant that the students' grades were still under KKM. Furthermore, the average class using mathematics handout based on the contextual approach was 80,00 which meant that classically it has shown a mastery.

The development of mathematics handout based on this contextual approach was considered to be effective if more than $70 \%$ of students get the value of $\geq \mathrm{KKM}$. Based on the result of final test analysis, it can be concluded that the mathematics handout based on the contextual approach has been effective since more than $70 \%$ got the value above KKM. Judging from the category of early mathematics abilities (KAM) of students there was an enhanced ability to solve mathematics problems of students whose learning using mathematics handouts based on the contextual approach. This showed that mathematics handout based on the contextual approach has been effective in enhancing the mathematics problem-solving ability of students.

\section{Conclusions}

This research produces mathematics handout based on a contextual approach that :1) Valid for the construction aspect, the content, the language, and the aspect of graphics; 2) Practical for the aspect of ease, the attractiveness aspect, the aspect of easy to be understood, handout benefits aspect, and for the time efficiency aspect; and 3) Effective to improve the ability of solving mathematics problems of 
grade VII students, because learning using contextual-based handouts provides activities that can facilitate learners to practice their mathematical problem-solving ability.

\section{Acknowledgments}

The writer wish to thank Dr. Armiati, M.Pd and Dr. Yerizon, M. Si as the academic advisors and postgraduate lecturers of State University of Padang who have given guidance and direction with sincere heart and patient in the completion of this article. This article is part of a thesis written by Alimatu Saqdiah entitled "Learning instruments Development On Contextual Based-Approach to Improve the Problem Solving Ability of Grade VII Students".

\section{References}

Afandi, J. (2017). Pengembangan pembelajaran matematika dengan pendekatan kontekstual budaya Lombok. Beta, 10(1), 1-17. https://dx.doi.org/10.20414/betajtm.v9i2.83

Gilar, M. J. (2016). Peningkatan kemampuan pemecahan masalah matematis peserta didik smp melalui pembelajaran dengan pendekatan kontekstual. Jurnal THEOREMS (The Original Research of Mathematics, 1 (1), 35-44.

Gusmania, Y. (2012). Pengembangan pembelajaran matematika dengan model pembelajaran kooperatif tipe think-pair-share untuk meningkatkan kompetensi peserta didik kelas VIII SMP Negeri 4 Sutera. PPS, Universitas Negeri Padang.

Hosnan, M. (2014). Pendekatan saintifik dan kontekstual dalam pembelajaran abad 21 kunci sukses implementasi kurrikulum 2013. Bogor : Ghalia Indonesia.

Husna, M. (2013). Peningkatan kemampuan pemecahan masalah dan komunikasi matematis peserta didik SMP melalui model pembelajaran kooperatif tipe think-pair-share (TPS). Jurnal Peluang, 1 (2), 82-91.

Hutagaol, K. (2013). Pembelajaran kontekstual untuk meningkatkan kemampuan representasi matematis peserta didik Sekolah Menengah Pertama. Jurnal Imiah Pendidikan Matematika, 2 (1), 85-91.

Nabila, A. L. (2017). Pengembangan pembelajaran berbasis pendekatan kontekstual pada materi bangun datar berorientasi pada pemahaman konsep peserta didik kelas VII SMP. Jurnal Pendidikan Matematika, 6 (7), 58-71.

Plomp, T. (2013). An introduction to educational design research. SLO, Netherlands Institute for Curriculum Development.

Sari, T. N. (2014). Implementasi pendekatan contextual teaching and learning (CTL) bernuansa pendidikan karakter untuk meningkatkan kemampuan pemecahan masalah matematis peserta didik MTsN. Jurnal Didaktik Matematika, 1 (1), 46-60.

Simanungkalit, H. R. (2016). Pengembangan pembelajaran untuk meningkatkan kemampuan pemecahan masalah matematis peserta didik SMP Negeri 12 Pematangsiantar. Journal of Mathematics Education, Science and Technology, 1 (1), 39-56.

Trianto. (2010). Model-model pembelajaran inovatif berorientasi konstruktivistik. Jakarta : Prestasi Pustaka. 